\title{
Pendampingan Literasi Dasar Tahap Pengembangan di SD Kristen YBPK Kota Malang
}

\author{
Eni Maharsi, Aris Siswanti, Melania Shinta Harendika \\ Departemen Bahasa dan Sastra, Fakultas Ilmu Budaya, Universitas Brawijaya \\ Jl. Veteran, Malang, 65145, Indonesia
}

\author{
ARTICLE INFO \\ Received: 2020-09-30 \\ Revised: 2020-11-03 \\ Accepted: 2021-01-17 \\ Keywords: \\ Basic literacy \\ movement, \\ Development stage, \\ Implementation, YBPK \\ Christian Elementary \\ School
}

\begin{abstract}
The implementation of Basic School Literacy Movement is supposed to be a shared responsibility, namely among parents, family, teachers, and the nation. But, notwithstanding it, this movement faces various obstacles in its implementation, including the students' reading and writing abilities, the parents' economic background, and the competence of teachers as the central agents in the Basic Literacy Movement. These obstacles are being faced by YBPK Christian Elementary School Malang City. Thus, this community service programme aims at assisting and supporting the school in carrying out basic literacy movement in the development stage. The programme design includes two activity by considering teachers and student sides. The teachers were provided with training on how to teach basic literacy and with assistance in implementing the teaching method in development stage of literacy. The students were given activities designed to focus on achieving Story Discussion skills. Toward this end, teachers and students were equipped with Literacy Love Board Method as a tool to recognize and appreciate students' active participation in the daily reading literacy. This Community Service Programme is expected to enhance basic literacy in the development stage towards the creation of a physical, social, affective, and academic literacy school environment.
\end{abstract}

(C) 2021 Published by University of Merdeka Malang. This is an open access article distributed under the CC BY-SA 4.0 license (https://creativecommons.org/licenses/by-sa/4.0/)

How to cite: Maharsi, E., Siswanti, A., \& Herendika, M. S. (2021). Pendampingan Literasi Dasar Tahap Pengembangan di SD Kristen YBPK Kota Malang. Abdimas: Jurnal Pengabdian Masyarakat Universitas Merdeka Malang, 6(1), 99-113. https://doi.org/10.26905/abdimas.v6i1.5007

\section{PENDAHULUAN}

Menumbuhkan minat baca tulis siswa melalui gerakan literasi merupakan suatu hal yang penting dalam upaya mencerdaskan kehidupan bangsa dan meningkatkan martabat bangsa Indonesia di dunia. gerakan literasi dasar bagi siswa pendidikan dasar merupakan salah satu upaya penting menumbuhkan bibit unggul bangsa (Teguh, 2015). Sekolah menjadi suatu lembaga yang bertanggung jawab mewujudkan budaya baca sebagai bagian penting dalam kegiatan belajar. Sekolah harus dapat memfasilitasi sarana yang dapat meningkatkan minat baca siswa, antara lain dengan dengan memanfaatkan perpustakaan sekolah (Rohim \& Rahmawati, 2020). 
ABDIMAS: Jurnal Pengabdian Masyarakat Universitas Merdeka Malang Volume 6, No. 1, February 2021: 99-113

Sejak tahun 2016 Kementerian Pendidikan dan Kebudayaan menggiatkan Gerakan Literasi Nasional (GLN) sebagai bagian dari implementasi dari Peraturan Menteri Pendidikan dan Kebudayaan Nomor 23 Tahun 2015 tentang Penumbuhan Budi Pekerti (Kementerian Pendidikan dan Kebudayaan, 2016). Selain sebagai upaya menyiapkan siswa dengan kemampuan menjalani kehidupan berkompetisi di era global, pemrograman literasi dasar dengan baik akan menghasilkan bibit sumber daya manusia yang mampu memilih dan memilah informasi dengan lebih baik. Literasi informasi merupakan kunci keberhasilan pembelajaran di era informasi (Andayani, 2008). Orang yang memiliki literasi informasi mampu mengelola pengetahuan yang dimilikinya sebagai dasar pengambilan keputusan yang mendasari langkahnya. Untuk sampai pada literasi informasi tentunya diperlukan upaya dini literasi, yakni dasar bagi siswa sekolah dasar. Literasi pada jenjang sekolah dasar sangat penting untuk digiatkan secara maksimal karena masih rendahnya literasi pada jenjang ini. Berdasarkan hasil tes Indonesian National Assessment Programme (INAP), tes yang mengambil sampel siswa kelas empat di tiga puluh empat provinsi di Indonesia menunjukkan bahwa kemampuan literasi membaca, matematika, dan sains siswa masih sangat rendah (Kementerian Pendidikan dan Kebudayaan, n.d).

Kegiatan literasi untuk siswa sekolah dasar masih dikategorikan sebagai literasi dini, terutama apabila siswa belum atau sangat sedikit terpapar pada kegiatan literasi. Sebagai sebuah gerakan nasional, pihak yang diharapkan aktif untuk menumbuhkan literasi dini ini adalah orang tua, keluarga, dan guru. Program gerakan literasi dasar di SDK YBPK Kota Malang juga telah diinisiasi oleh tim pengabdian masyarakat Fakultas Ilmu Budaya Universitas Brawijaya pada tahun 2019 dan terus berlangsung hingga tahun 2020. Temuan hasil kegiatan tahun 2019 adalah bahwa situasi literasi peserta didik di sekolah ini masih berada pada tingkat literasi dini (Harendika et al., 2019). Siswa masih banyak menggunakan bahasa ibu atau bahasa daerah dan belum banyak menggunakan bahasa Indonesia di sekolah. Oleh karena itu, kegiatan literasi diprogram dalam skema tahap pembiasaan, yakni berupa kegiatan membaca 15 menit setiap hari.

Untuk program gerakan literasi dasar tahap 2 ini, tim pengabdian merancang skema kegiatan dan materi berdasar hasil masukan kepala sekolah SD YBPK. Masukan terkait kendala yang dihadapi sekolah dalam menjalankan gerakan literasi dini. Pertama, kegiatan membaca 15 menit per hari terus berlangsung, namun sebagian siswa masih belum mampu atau belum bersedia memberikan respon terhadap bacaan, misalnya belum mampu menceritakan ulang isi bacaan secara lisan atau tertulis. Kedua, sebagian besar siswa berasal dari keluarga menengah pra sejahtera di mana orang tua bekerja sebagai pekerja harian atau swasta dengan penghasilan tidak tetap. Hal ini memang merupakan salah satu tantangan dalam dunia literasi Indonesia di mana figur teladan "pembaca" di rumah, sekolah, dan lingkungan sangat kurang (Muradi, n.d.). Orang dewasa belum mampu menjadi teladan yang memberi contoh bahwa membaca merupakan kegiatan yang menenangkan, menghibur, dan menyenangkan. Ketiga, guru sekolah memiliki kualifikasi akademik selain bidang pendidikan sekolah dasar. Kendala-kendala serta situasi ini menjadikan kegiatan literasi menjadi kurang maksimal dan berimplikasi pentingnya keberlanjutan program gerakan literasi dasar baca tulis di SD Kristen YBPK Kota Malang. Tahap pembiasaan yang telah dilakukan perlu dilanjutkan ke arah tahap pengembangan, di mana guru diperkenalkan dan didampingi untuk merancang kegiatan membaca yang lebih bervariasi dan serta dapat memotivasi guru dan siswa untuk lebih tertarik dan bersemangat mengikuti Program Gerakan Literasi Dasar. Siswa perlu diperkenalkan dengan kegiatan 
membaca yang bermanfaat dan menyenangkan. Kegiatan pengabdian kepada masyarakat Fakultas Ilmu Budaya ini bertujuan untuk mendampingi dan mendukung sekolah dalam melakukan literasi dasar tahap pengembangan baca tulis menuju terciptanya lingkungan sekolah literasi, baik lingkungan fisik, sosial afektif, maupun akademik.

Upaya gerakan literasi sekolah merupakan suatu bentuk dukungan kepada pemerintah dalam upaya menanamkan budi pekerti dari semenjak pendidikan dasar (Wulanjani \& Anggraeni, 2019). Pentingnya kemampuan literasi telah menjadi perhatian besar peneliti-peneliti sebelumnya. Setiawan \& Sudigdo (2019) memaparkan hasil penelitiannya mengenai penguatan literasi siswa sekolah dasar melalui kunjungan perpustakaan. Program kunjungan perpustakaan didesain sebagai kegiatan yang sudah tersusun dan terencana yang di terapkan kepada siswa secara wajib untuk mengunjungi perpustakaan dan melaksanakan kegiatan literasi. Batubara \& Ariani (2018) memaparkan hasil penelitian terkait pelaksanaan program gerakan literasi sekolah di SDN Gugus Sungai Miai Banjarmasin. Mereka menemukan bahwa pelaksanaan program gerakan literasi sekolah di di sekolah ini masih berada pada tahap pembiasaan. Upaya sekolah dalam melaksanakan program gerakan literasi sekolah adalah: (1) menambah buku pengayaan; (2) mendekatkan buku ke peserta didik dengan cara membuat area baca dan lingkungan yang kaya akan teks; (3) melaksanakan berbagai bentuk kegiatan literasi; dan (4) melibatkan publik dalam pelaksanaan gerakan literasi.

Kedua penelitian tadi memperkuat pandangan pentingnya menerapkan kegiatan yang tepat dalam upaya peningkatan literasi siswa sehingga dapat membawa dampak positif bagi siswa khususnya terkait dengan budaya literasi di sekolah. Akan tetapi kedua penelitian tersebut belum meninjau secara mendalam penerapan gerakan literasi di sekolah. Untuk itu, penelitian ini hadir untuk memberikan pengetahuanpengetahuan baru terutama terkait dengan berbagai kegiatan menarik yang dapat diterapkan di sekolah dalam upaya penerapan gerakan literasi khususnya literasi membaca tahap pengembangan. Selain itu penelitian ini juga memberikan tindak lanjut yang dapat diadopsi oleh sekolah-sekolah lain sebagai upaya menjaga terlaksananya gerakan literasi membaca secara berkelanjutan di sekolah (programme sustainability).

\section{METODE}

Pendekatan yang digunakan dalam penelitian ini adalah pendekatan kualitatif. Penelitian ini dimaksudkan untuk menguraikan dan mendeskripsikan dampak Pelaksanaan Gerakan Literasi Dasar Tahap Pengembagan terhadap minat baca siswa SD YBPK Kota Malang. Penelitian kualitatif ini menguraikan hasil dalam bentuk deskripsi dan kata-kata. Rancangan pemecahan masalah mencakupi dua tahapan kegiatan dengan mempertimbangkan sisi guru dan siswa.

\section{Kegiatan untuk Guru}

Sebagai realisasi pemecahan masalah dalam mengajar dan membimbing anak-anak dalam memperoleh literasi dasar, maka guru-guru diberi pembekalan cara mengajarkan literasi dasar tahap pengembangan, dan pendampingan dalam implementasi tahap pengembangan. Kegiatan dilaksanakan dalam skim lokakarya dan pendampingan bagi guru dalam memetakan materi literasi yang berterima 
ABDIMAS: Jurnal Pengabdian Masyarakat Universitas Merdeka Malang

Volume 6, No. 1, February 2021: 99-113

dengan kemampuan siswa dengan mempertimbangkan materi yang telah disasar pada tahap pembiasaan.

\section{Kegiatan untuk Siswa}

SD Kristen YBPK Kota Malang memiliki tata kelola yang berbeda dari sekolah pada umumnya karena jumlah siswa peserta kelas yang sangat sedikit. Namun demikian hal ini justru memiliki sisi positif. Kegiatan tindak lanjut dalam tahap pengembangan literasi memerlukan waktu pembiasaan sekitar 15 menit. Dengan kondisi kelas yang kecil, maka guru dapat lebih menyesuaikan kondisi siswa masingmasing. Sehingga kegiatan literasi tetap dapat dilaksanakan dengan menyenangkan tanpa membebani tugas para siswa. Dengan merujuk pada Buku Panduan Gerakan Literasi Sekolah Dasar (2016) maka kegiatan untuk siswa dirancang untuk fokus mencapai kemampuan mendiskusikan cerita. Tim PKM FIB juga memperkenalkan metode "Papan Cinta Literasi", sebagai bentuk rekognisi dan apresiasi partisipasi siswa dalam kegiatan literasi membaca harian tersebut. Instrumen untuk mengumpulkan data dipaparkan secara prosedural sebagai berikut.

\section{Wawancara}

Sub kegiatan pertama yang akan dilakukan adalah wawancara dengan kepala sekolah SD YBPK Ngaglik, Kota Malang untuk mengetahui kondisi pelaksanaan kegiatan literasi sekolah serta kebutuhan sekolah untuk gerakan literasi tahap pengembangan. Tujuannya adalah untuk menyusun materi dan strategi literasi dasar tahap pengembangan termasuk pemahaman khalayak sasaran, kebutuhan yang harus terjawab, kemampuan yang sudah ada dan seterusnya. Wawancara dilakukan dua kali yakni pada tanggal 12 April 2020 dan 3 Mei 2020.

\section{Lokakarya dan Focus Group Discussion}

Kegiatan ini diperuntukkan bagi kepala sekolah dan guru tentang mekanisme dan strategi pelaksanaan literasi dasar tahap pengembangan bagi siswa. Sebagai realisasi pemecahan masalah dalam mengajar dan membimbing anak-anak memperoleh literasi dasar tahap pengembangan, maka guru-guru akan mendapatkan pembekalan cara mengajarkan literasi tahap pengembangan, dan pendampingan dalam implementasi strategi pengembangan sekolah literasi. Melanjuti kegiatan ini, maka tim PKM FIB mengadakan FGD (Focus Group Discussion) di SDK YBPK Kota Malang yang dilaksanakan pada hari Kamis, 6 Agustus 2020 dan monitoring dan evaluasi pada hari Selasa, 22 Oktober 2020.

\section{Kegiatan literasi membaca di kelas dan pendampingan}

Setelah lokakarya, dilakukan kegiatan literasi membaca di kelas untuk siswa dipandu guru masing-masing. Guru mengisi lembar observasi digunakan untuk mengamati respon siswa selama kegiatan literasi tersebut. Hasil observasi ini juga yang menjadi bahan diskusi dengan tim pengabdian

yang mendampingi guru selama kegiatan literasi membaca berlangsung. Komunikasi untuk masa 
pendampingan dilakukan melalui komunikasi elektronik. Kegiatan dilaksanakan selama tujuh bulan, yakni dari April-Oktober 2020.

\section{Pengadaan buku bacaan penunjang dan "Papan Cinta Literasi"}

Sebagai bentuk komitmen tim pengabdian FIB untuk mendukung tahap pengembangan literasi di SD Kristen YBPK Kota Malang dan perintisan taman baca dan Pusat Kegiatan Belajar Masyarakat (PKBM), tim pengabdian menyediakan buku-buku bacaan berbentuk hard copy dan soft copy. Tim pengabdian juga menyediakan papan tulis dan alat tulis yang akan digunakan sebagai "Papan Cinta Literasi" untuk mencatat capaian siswa dalam kegiatan literasi membaca setiap hari.

\section{Penyusunan konstruk penilaian non-akademik}

Pengembangan konstruk instrumen menduduki posisi penting dalam penentuan aspek-aspek penilaian kompetensi literasi (Musfiroh \& Listyorini, 2016). Konstruk yang sudah dikembangkan akan menjadi kerangka acuan dalam mengembangkan instrumen penilaian baik dalam bentuk tes maupun nontes. Merujuk Knapp dan Watkins, penelitian ini menggunakan konstruk Kompetensi Literasi untuk Siswa Sekolah Dasar terhadap berbagai bentuk genre berbahasa dan berkomunikasi. Konstruk ini juga dikenal sebagai pendekatan genre yang tidak terlepas dari konsep literasi karena dalam pendekatan ini, teks memiliki genre tertentu yang kemudian dilihat relevansi dan praktiknya pada konteks nyata, seperti teks dalam media cetak maupun elektronik (Knapp \& Watkins, 2005; Musfiroh \& Listyorini, 2016). Dengan menggunakan konstruk penilaian ini, sumber penilaian nonakademik yang digunakan di SDK YBPK Kota Malang adalah: (1) portofolio sederhana karya siswa dalam kegiatan menanggapi bacaan; dan (2) lembar pengamatan tenaga pendidik pada setiap kegiatan membaca. Namun demikian, rubrik penilaian lebih difokuskan pada penggunaan lembar pengamatan guru.

\section{HASIL DAN PEMBAHASAN}

Hasil kegiatan Gerakan Literasi dasar tahap pengembangan di SD Kristen YBPK dipaparkan berdasarkan capaian kegiatan yang dilaksanakan oleh guru serta capaian kegiatan yang dilaksanakan oleh siswa.

\section{Capaian Kegiatan yang Dilaksanakan oleh Guru}

Capaian kegiatan ini mencakupi: (1) gerakan literasi tahap pengembangan per tingkat Kelas; (2) pemilihan buku; (3) apresiasi capaian literasi siswa; dan (4) mencontohkan literasi tahap pengembangan yang diuraikan sebagai berikut.

\section{Gerakan literasi tahap pengembangan per tingkat kelas}

Fokus kegiatan tahap pengembangan literasi SD kelas rendah (kelas 1-3) adalah guru melakukan kegiatan membacakan nyaring interaktif, memandu siswa dalam membaca buku bergambar (guided 
ABDIMAS: Jurnal Pengabdian Masyarakat Universitas Merdeka Malang Volume 6, No. 1, February 2021: 99-113

reading), membaca buku bergambar bersama siswa, dan siswa menggambar tokoh kejadian dalam cerita, atau menulis beberapa kata dari cerita. Media yang digunakan yaitu buku cerita bergambar serta buku cerita bergambar besar (big book).

Untuk kelas 4, 5, dan 6, kegiatan membaca menggunakan metode membaca nyaring, membaca bersama (shared reading), membaca terpandu (guided reading), dan membaca dalam hati. Peserta didik dapat mengisi peta cerita serta menuliskan tanggapan atau kesan terhadap bacaan dengan kalimat sederhana. Media yang digunakan untuk SD kelas tinggi yaitu buku cerita bergambar, buku cerita berilustrasi, big book, cerita rakyat yang sesuai jenjang SD, novel anak sederhana. Guru kelas 6 juga sudah mulai menggunakan media audio-visual video yang disaksikan bersama untuk kemudian didiskusikan isinya bersama siswa.
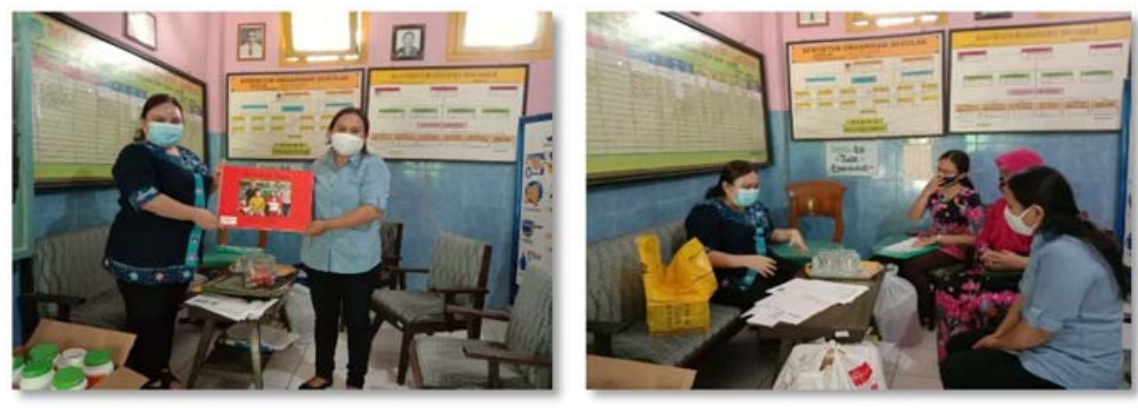

Gambar 1. Serah terima bantuan buku bacaan dan big books

\section{Pemilihan buku}

Buku yang digunakan adalah buku fiksi dan nonfiksi yang memiliki elemen cerita, ilustrasi, dan bahasa yang ditulis bertujuan untuk menumbuhkan minat baca pada peserta didik. Buku yang memiliki elemen cerita juga digunakan sebagai upaya guru meningkatkan apresiasi peserta didiknya terhadap sastra sehingga dapat menjadi model untuk mengembangkan kemampuan menulis kreatif. Buku yang dipilih yaitu buku yang tersedia dalam berbagai topik dan tema yang dapat didiskusikan dengan peserta didik untuk meningkatkan kemampuan berpikir mereka. Pemilihan buku pengayaan dilakukan berdasarkan elemen sampul muka, cerita atau konten informasi, dan kebahasaan.

\section{Apresiasi capaian literasi siswa}

Guru SDK YBPK Kota Malang mengapresiasi atas capaian peserta didik yang bisa dilihat dari sikap, kesungguhan, dan perilaku peserta didik dalam proses belajar dan membacanya. Bentuk apresiasi ini tidak selalu diberikan secara berkala setiap minggu. Namun, menyesuaikan dengan capaian siswa melalui media "Papan Cinta Literasi" sebagai bentuk awal apresiasi atas partisipasi peserta didik dalam kegiatan literasi.

\section{Mencontohkan literasi tahap pengembangan}

Tim PKM FIB menampilkan beberapa video contoh kegiatan membaca tahap pengembangan literasi, misalnya membaca big book bersama dengan guru. Kegiatan membaca dilakukan secara 
bertahap mulai dari mengenalkan tata tertib membaca bersama, membahas sampul buku dan penulis, dan seterusnya.
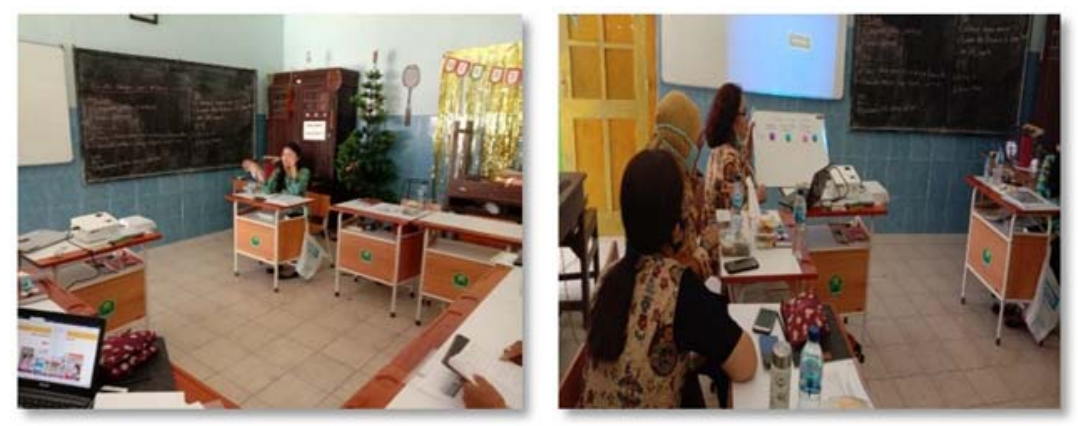

Gambar 2. Pendampingan eksplorasi media dan teknik membaca

\section{Capaian Kegiatan oleh Siswa}

Setiap guru melaksanakan kegiatan literasi di kelas masing masing dan melakukan observasi pada tanggal 10 Agustus-11 September 2020. Kegiatan membaca dilakukan secara luring untuk kelas 2, 4, dan 5. Sementara itu, untuk kelas 6 dilakukan secara daring. Hasil dari pengamatan guru terhadap aktivitas siswa pada program pengembangan literasi SD YBPK Kota Malang dirangkum dalam Tabel 1 dan Tabel 2.

Tabel 1. Ringkasan data hasil observasi kegiatan membaca kelas 2 (luring)

\begin{tabular}{llc}
\hline Variabel Data Observasi & Uraian & Frekuensi \\
\hline \multirow{2}{*}{ Waktu } & Sebelum pelajaran dimulai & 14 kali \\
& Sebelum sekolah berakhir & 9 kali \\
& Pencarian dimulai & 1 kali \\
& Majalah Bobo & 8 kali \\
& Kumpulan Dongeng Anak-Anak yang Tak Terlupakan & 3 kali \\
& Kumpulan Cerita Anak & 2 kali \\
& Cerita-cerita Alkitab & \\
Buku yang dibaca & Komik Sains Edisi 08 & 1 kali \\
& Komik Sains Edisi 06 & \\
& Komik Sains Edisi 02 & 2 kali \\
& Kuark & 1 kali \\
& Dongeng Kita & \\
\hline
\end{tabular}


ABDIMAS: Jurnal Pengabdian Masyarakat Universitas Merdeka Malang Volume 6, No. 1, February 2021: 99-113

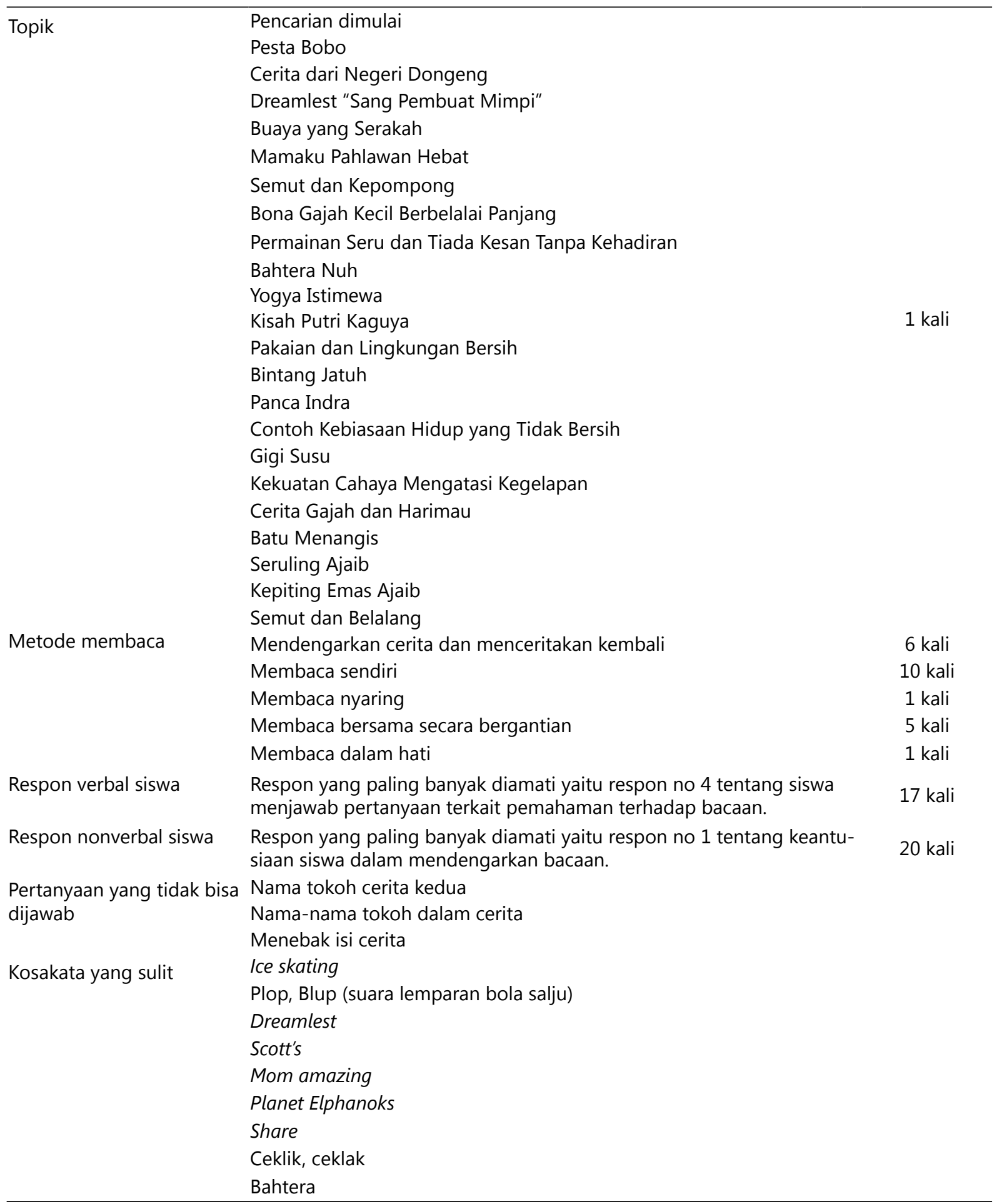


Tabel 2. Ringkasan data hasil observasi kegiatan membaca kelas 4 (luring)

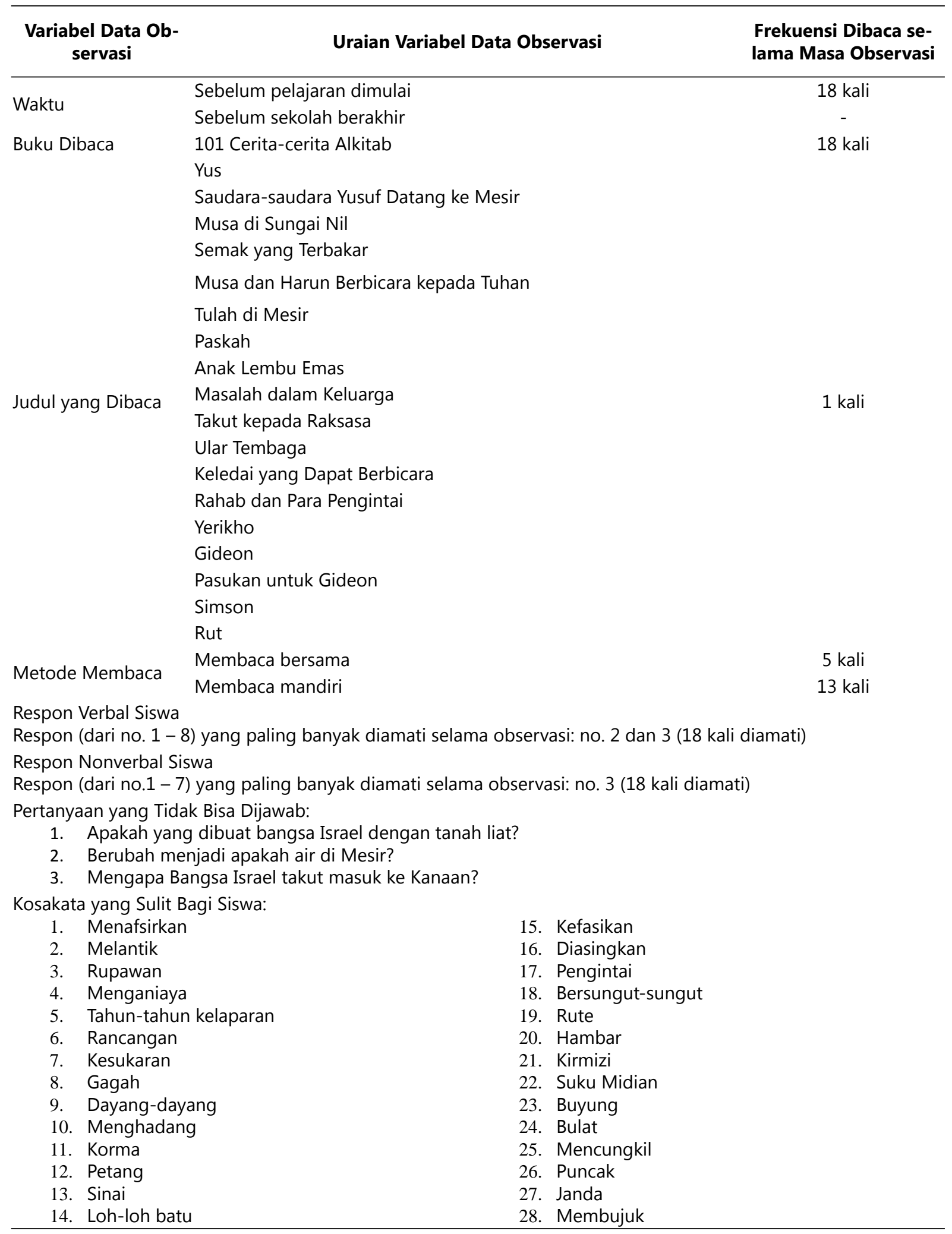


ABDIMAS: Jurnal Pengabdian Masyarakat Universitas Merdeka Malang Volume 6, No. 1, February 2021: 99-113

Tabel 3. Ringkasan data hasil observasi kegiatan membaca kelas 5 (luring)

\begin{tabular}{|c|c|c|}
\hline Variabel Data Observasi & Uraian Variabel Data Observasi & $\begin{array}{l}\text { Frekuensi Dilakukan/Dibaca } \\
\text { selama Masa Observasi }\end{array}$ \\
\hline \multirow[t]{2}{*}{ Waktu } & Sebelum pelajaran dimulai & 7 kali \\
\hline & Sebelum sekolah berakhir & 15 kali \\
\hline \multirow[t]{2}{*}{ Buku yang Dibaca } & 101 Cerita-cerita Alkitab & 21 kali \\
\hline & Kisah Ikan Kecil Mencari Air & 1 kali \\
\hline \multirow[t]{20}{*}{ Topik yang Dibaca } & Yakub Menerima Berkat & \\
\hline & Yakub Melarikan Diri & \\
\hline & $\begin{array}{l}\text { Yakub Ditipu, Bergumul dengan Seorang } \\
\text { Malaikat }\end{array}$ & \\
\hline & Mimpi dan Pesan Khusus & \\
\hline & Yusuf Menafsir Mimpi Firaun & \\
\hline & Musa di Sungai Nil & \\
\hline & Semak yang Terbakar & \\
\hline & Musa dan Harun Berbicara kepada Firaun & \\
\hline & Kisah Ikan Kecil yang Mencari Air & \\
\hline & Tulah di Mesir & \\
\hline & Paskah & 1 kali \\
\hline & Laut Merah Terbelah Dua & \\
\hline & $\begin{array}{l}\text { Allah Menyediakan Makanan di Padang Gurun } \\
\text { (Manna \& Puyuh) } \\
\text { Sepuluh Perintah Allah }\end{array}$ & \\
\hline & Anak Lembu Emas & \\
\hline & Masalah dalam Keluarga & \\
\hline & Takut kepada Raksasa & \\
\hline & Ular Tembaga & \\
\hline & Keledai yang Dapat Berbicara & \\
\hline & Rahab dan Pengintai & \\
\hline & Yerikho & \\
\hline \multirow[t]{4}{*}{ Metode Membaca } & Membaca bersama & 9 kali \\
\hline & Membaca mandiri & 8 kali \\
\hline & Membaca terbimbing & 2 kali \\
\hline & Membaca nyaring & 3 kali \\
\hline \multicolumn{3}{|c|}{ g banyak diamati selama observasi: no. 1, 2, 3 dan 4 (22 kali diamati) } \\
\hline \multicolumn{3}{|c|}{$\begin{array}{l}\text { Respon Nonverbal Siswa } \\
\text { Respon (dari no.1 - 7) yang paling banyak diamati selama observasi: no. 1, 3, dan } 4 \text { (22 kali diamati) }\end{array}$} \\
\hline \multicolumn{3}{|c|}{ Pertanyaan yang Tidak Bisa Dijawab: - } \\
\hline
\end{tabular}




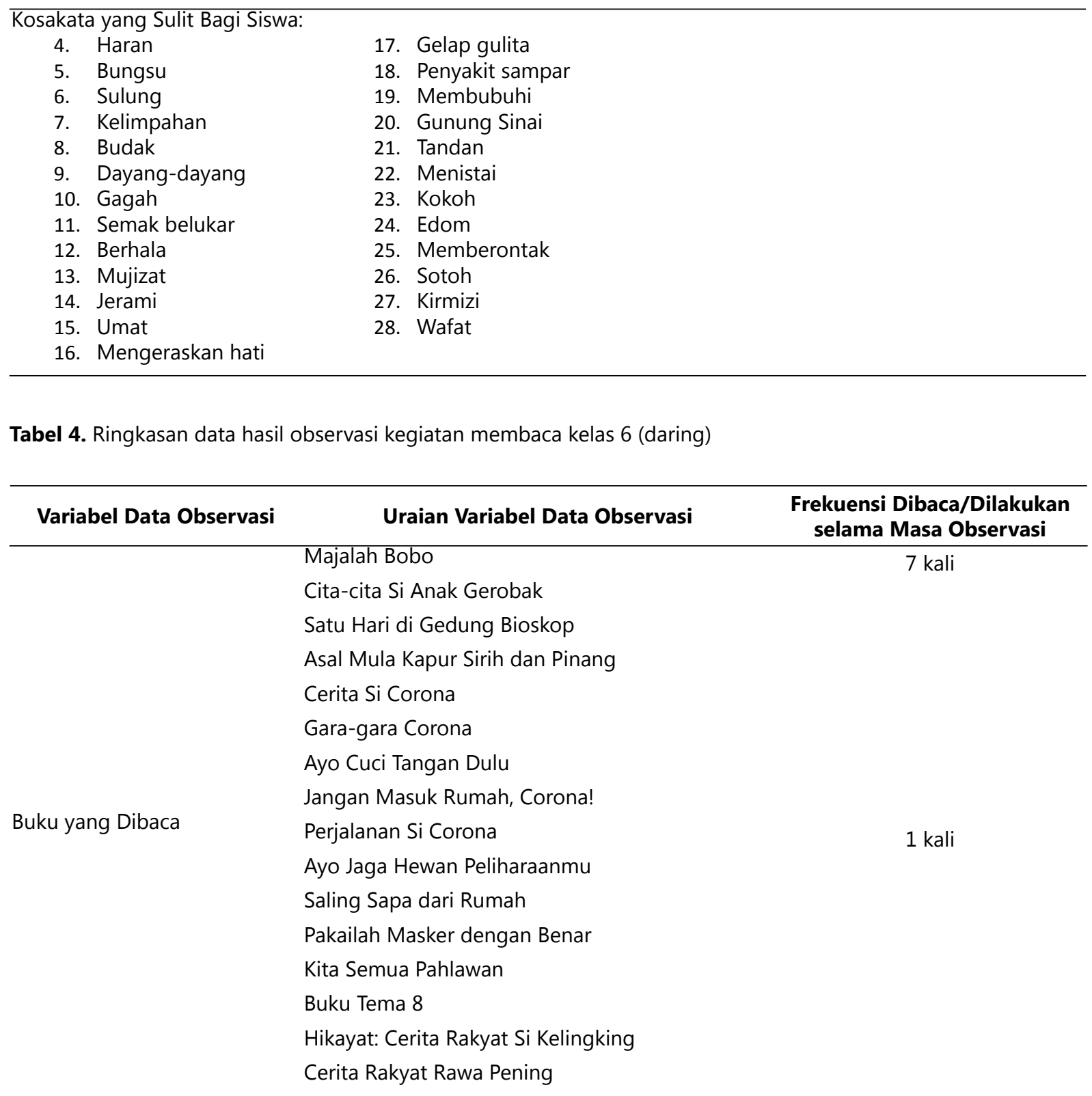


ABDIMAS: Jurnal Pengabdian Masyarakat Universitas Merdeka Malang Volume 6, No. 1, February 2021: 99-113

\begin{tabular}{|c|c|c|}
\hline \multirow[t]{22}{*}{ Topik yang Dibaca } & \multicolumn{2}{|l|}{ Rajawali Harpa } \\
\hline & \multicolumn{2}{|l|}{ Bersepeda dengan Ayah } \\
\hline & \multicolumn{2}{|l|}{ Tompel Hilang dan Tikus Kecil Pintar } \\
\hline & \multicolumn{2}{|l|}{ Hewan Peliharaan } \\
\hline & \multicolumn{2}{|l|}{4 Manfaat Memelihara Hewan } \\
\hline & \multicolumn{2}{|l|}{ Ramayana, Petualangan Tikus Cerobong } \\
\hline & \multicolumn{2}{|l|}{ Bona } \\
\hline & \multicolumn{2}{|l|}{ Cita-cita Si Anak Gerobak } \\
\hline & \multicolumn{2}{|l|}{ Satu Hari di Gedung Bioskop } \\
\hline & \multicolumn{2}{|l|}{ Asal Mula Kapur Sirih } \\
\hline & \multicolumn{2}{|l|}{ Cerita Si Corona } \\
\hline & \multicolumn{2}{|l|}{ Gara-gara Corona } \\
\hline & \multicolumn{2}{|l|}{ Ayo Cuci Tangan Dulu } \\
\hline & \multicolumn{2}{|l|}{ Jangan Masuk Rumah, Corona } \\
\hline & \multicolumn{2}{|l|}{ Perjalanan Si Corona } \\
\hline & \multicolumn{2}{|l|}{ Ayo Jaga Hewan Peliharaanmu } \\
\hline & \multicolumn{2}{|l|}{ Saling Sapa dari Rumah } \\
\hline & \multicolumn{2}{|l|}{ Pakailah Masker dengan Benar } \\
\hline & \multicolumn{2}{|l|}{ Kita Semua Pahlawan } \\
\hline & \multicolumn{2}{|l|}{ Si Badang } \\
\hline & \multicolumn{2}{|l|}{ Cerita Rakyat Si Kelingking } \\
\hline & \multicolumn{2}{|l|}{ Cerita Rakyat Rawa Pening } \\
\hline Metode Membaca & Membaca Mandiri & 22 kali \\
\hline \multicolumn{3}{|c|}{$\begin{array}{l}\text { Aspek Kognitif } \\
\text { Semua aspek terisi "ya" dan jumlahnya tiap pertemuan telah sesuai dengan jumlah siswa yang ada. }\end{array}$} \\
\hline \multicolumn{3}{|c|}{$\begin{array}{l}\text { Aspek Proses } \\
\text { Semua aspek terisi "ya" dan jumlahnya tiap pertemuan telah sesuai dengan jumlah siswa yang ada. }\end{array}$} \\
\hline \multicolumn{3}{|c|}{ Kosakata yang Sulit Bagi Siswa: - } \\
\hline \multicolumn{3}{|c|}{ Kesulitan dalam Membaca/Mengerjakan Tugas Daring: - } \\
\hline
\end{tabular}

Dari pembacaan tabel-tabel di atas, metode membaca yang paling sering digunakan ialah metode membaca mandiri sebanyak 53 kali. Untuk jenis teks, teks narasi merupakan teks yang paling sering dibaca oleh keseluruhan siswa, baik dari kelas tinggi maupun kelas rendah.

\section{Pembahasan}

Hasil program gerakan literasi tahap pengembangan disampaikan dalam FGD pada tanggal dimonitor dan dievaluasi pelaksanaannya hari Selasa, 22 Oktober 2020 melalui Zoom Cloud Meeting atau daring. Hasil monitoring dan evaluasi terhadap gerakan literasi tahap pengembangan di SDK YBPK Kota Malang digambarkan berdasar kelas rendah dan kelas tinggi. 


\section{Pendampingan Literasi Dasar Tahap Pengembangan di SD Kristen YBPK Kota Malang \\ Eni Maharsi, Aris Siswanti, Melania Shinta Harendika}
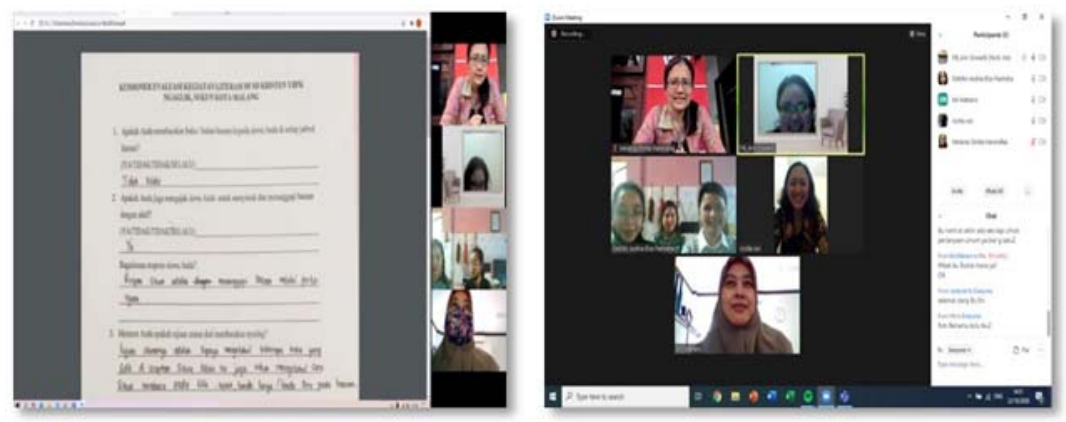

Gambar 3. Monitoring dan evaluasi beserta contoh lembar isian evaluasi

Untuk kelas rendah (kelas 2 dan 3) jadwal literasi adalah tiap hari, namun jam tidak terjadwal ketat bisa pagi atau siang. Durasi literasi sekira 30 menit. Metode membaca nyaring dilakukan secara selang-seling, guru-siswa, siswa-guru; role play untuk bacaan di mana ada percakapan. Sementara bacaan diulang jika ada pertanyaan yang belum dipahami jawabannya. Kosakata baru diperkenalkan manakala siswa membaca kata tersebut. Kelas dua ada yang sudah bisa membaca lancar, namun ada pula yang terbaca-bata. Jika diminta membaca maka siswa akan membaca namun tidak pernah meminta atau mengingatkan sesi baca. Fasilitas pendukung pensil dan kertas, papan magnet, dan magnet. Siswa menandai di papan jika sudah membaca mandiri. Guru kelas menyatakan bahwa siswa senang dengan kegiatan menandai capaiannya dalam membaca mandiri.

Untuk kelas tinggi, yakni kelas 5, literasi dijadwalkan d akhir pelajaran selama 30 menit setiap hari. Ada dua bentuk kegiatan membaca yang dilakukan guru yakni nyaring dan membaca dalam hati. Kegiatan membaca nyaring dilakukan selang-seling: guru-siswa, siswa-guru dalam satu materi baca per paragraph. Dalam kegiatan literasi ini, siswa kelas 5 aktif bertanya "mengapa?" dan "apa?". Yang banyak ditanyakan adalah kosakata atau istilah yang asing bagi siswa yang ditemukan setelah selesai membaca, bukan kosakata baru. Misalnya adalah pertanyaan "apa itu "dusta"?". Mengingat sekolah berbasis agama, maka mbacaan seringkali dari diambil dari Alkitab. Untuk fasilitas tambahan yang digunakan oleh guru dalam memotivasi siswa adalah magnet board, video, dan film anak-anak. Ada menggunakan metode ADIK SIMBA dengan pemberian reward untuk yang berhasil menjawab. Tagihan untuk kelas 5 ini berwujud instruksi membawa buku cerita dari rumah atau dipinjami oleh bu Guru (buku inventaris sekolah) dan diminta membuat pertanyaan sendiri darin materi yang sudah dibaca tersebut.

Untuk kelas tinggi kelas 4 dan 6, durasi pelaksanaan literasi harian adalah 30 menit setiap harinya. Metode literasi baca yang digunakan guru adalah metode membaca mandiri. Untuk kelas 4 kegiatan sekolah adalah luring dimana untuk literasi siswa diminta membaca nyaring, kadang dalam hati, serta bergiliran dengan guru membaca paragraf dalam satu cerita. Sementara untuk kelas 6 tagihan untuk literasi membaca adalah siswa merekam video membaca dan dikirim ke guru. Terkait respons siswa, siswa kelas 4 merespon dengan baik, tanpa disuruh segera bertanya, siswa juga memberi komentar takjub, dan gestur yang baik. Sedangkan siswa kelas 6 melalui video, sehingga agak sulit mendapat atau menilai respons baik siswa. Faktornya karena tidak di hadapan guru dan berhadapan dengan gadget sehingga tidak terlalu semangat. Untuk tagihan literasi kelas 4 adalah mencari kosakata baru. Kata yang tidak dipahami ditulis di atas flash card yang dari kertas karton dan kemudian ditempel di papan magnet. 
ABDIMAS: Jurnal Pengabdian Masyarakat Universitas Merdeka Malang

Volume 6, No. 1, February 2021: 99-113

Tujuannya untuk menggali kemampuan kosakata. Fasilitas tambahan yang digunakan guru adalah papan magnet, papan tulis, dan kertas karton.

\section{SIMPULAN DAN SARAN}

\section{Simpulan}

Penelitian ini telah mengidentifikasi beberapa capaian dan tantangan dari hasil gerakan literasi dasar tahap pengembangan di SD YBPK Kota Malang. Capaian utama adalah bahwa kegiatan literasi tahap pengembangan di SD YBPK Kota Malang telah tercapai, yakni menumbuhkan minat baca siswa. Capaian pertama kegiatan pengembangan literasi pada kelas rendah adalah meningkatnya kemampuan mengeja kalimat, memahami kata dan memahami alur cerita. Capaian kedua pada kelas tinggi dengan kegiatan bertujuan meningkatkan kemampuan membaca dengan lebih baik, menggunakan konteks kalimat untuk memaknai kata baru, serta memahami cerita fantasi juga telah tercapai. Namun demikian, beberapa tantangan juga teridentifikasi. Pertama, materi cerita rakyat dengan konteks budaya yang spesifik belum diberikan. Guru lebih cenderung menggunakan cerita-cerita keagaaman yang diambil dari Alkitab atau majalah anak-anak terbitan gereja. Kedua, sebagai kegiatan lanjutan dari kegiatan pembiasaan tahun 2019, tagihan sudah diberikan berbentuk sesuatu yang dibuat oleh siswa dari hasil membaca. Tagihan yang diberikan beragam dari variasi kegiatan menulis sesuatu tentang buku yang sudah dibaca, menggambar, serta membuat tempelan sederhana. Sejak kegiatan di tahap pembiasaan, guru menilai baik antusiasme dan perhatian siswa terhadap kegiatan literasi. Di sisi lain, tantangan situasi pandemi saat ini mengharuskan siswa kelas VI (pada saat lokakarya berlangsung) harus bersekolah secara daring. Siswa kelas 6 menggunakan bahan bacaan dalam format pdf karena kelas dilaksanakan secara daring. Dalam keterbatasan ini, guru mengalami kesulitan untuk memperoleh bahan bacaan yang dapat diakses daring, khususnya bacaan yang temanya sesuai dengan pendidikan karakter SD. Sebagai solusi tantangan literasi, guru-guru SD Kristen YBPK Kota Malang merancang jenis kegiatan membaca yang lebih ramah siswa (students friendly), yakni menyiapkan materi baca yang kemudian dibagikan kepada siswa secara person-to-person melalui WhatsApp orang tua siswa (untuk siswa kelas VI). Sementara untuk siswa kelas rendah, kegiatan literasi dibuat dalam bentuk: (1) membaca nyaring diikuti kegiatan tanya jawab tentang bacaan; dan (2) membaca bersama lalu diikuti kegiatan menggambar terkait dengan bacaan. Buku bacaan yang digunakan yaitu buku fiksi dan nonfiksi yang memiliki bahasan yang sesuai dengan usia siswa.

\section{Saran}

Dari pembahasan dan simpulan yang telah diambil, maka beberapa rekomendasi yang dapat diberikan adalah sebagai berikut. Pertama, sekolah perlu tetap melanjutkan gerakan literasi dasar sebagai upaya peningkatan kualitas siswa dan guru meski ada kendala-kendala fasilitasi lingkungan literasi di sekolah. Kedua, upaya merintis berdirinya Taman Baca dan Pusat Kegiatan Belajar Masyarakat (PKBM) sebaiknya terus dilaksanakan dan diupayakan. Mencari dukungan dari berbagai pihak yang memiliki perhatian terhadap Gerakan Literasi Dasar, terutama untuk sekolah-sekolah under-resourced perlu dilakukan semisal mengajukan kepada universitas atau Pemerintah Kota Malang. Ketiga, Tim Pengabdian kepada Masyarakat dari Fakultas Ilmu Budaya perlu terus mendampingi keberlanjutan (sustainability) 
Gerakan Literasi Dasar di SDK YBPK Kota Malang. Tim pengabdian juga perlu mempertimbangkan pentingnya kreativitas dalam pengembangan literasi. Melalui pemahaman lingkungan sekolah, siswa, dan guru maka kegiatan selanjutnya dapat dirancang secara lebih bermakna (meaningful) dan berdaya guna serta menarik (engaging), misalnya memberi pelatihan cara mengajar story telling kepada guru.

\section{Ucapan Terima Kasih}

Tim Penulis menghaturkan terima kasih kepada Dekan Fakultas Ilmu Budaya Universitas Brawijaya atas dukungan dan fasilitas baik pendanaan maupun sumber daya tambahan terhadap program pengabdian kepada masyarakat ini. Ucapan terima kasih juga disampaikan kepada Kepala Sekolah dan Guru-guru SDK YBPK Kota Malang atas Kerjasama serta upaya maksimalnya dalam menjalankan Rangkaian Program Gerakan Literasi Dasar.

\section{DAFTAR PUSTAKA}

Andayani, S. (2008). Information literacy kunci sukses pembelajaran di era informasi. Diakses dari http://staffnew.uny.ac.id/upload/132162018/penelitian/Information+Literacy+Kunci+Sukses +Pembelajaran+Di+Era+Informasi.pdf

Batubara, H. H., \& Ariani, D. N. (2018). Implementasi program gerakan literasi sekolah di Sekolah Dasar Negeri Gugus Sungai Miai Banjarmasin. JPSD (Jurnal Pendidikan Sekolah Dasar), 4(1), 15-29. http://dx.doi.org/10.30870/jpsd.v4i1.2965

Kementerian Pendidikan dan Kebudayaan. (2016). Tentang GLN: Kilasan gerakan literasi nasional. Diakses dari https://gln.kemdikbud.go.id/glnsite/tentang-gln/

Kementerian Pendidikan dan Kebudayaan. (n.d). Statistik Nasional: Sekolah Dasar. Balitbang: Pusat Penilaian Pendidikan. Diakses dari pusmenjar.kemdikbud.go.id/inap-sd/

Harendika, M.S., Maharsi, E., \& Siswanti, A. (2019). Strengthening the students' literacy in YBPK Elementary School Ngaglik Sukun Malang. Laporan Penelitian (Tidak dipublikasi).

Muradi, R. (n.d) Pentingnya Gerakan Membaca di Sekolah Dasar. Diakses dari http://literasi.jabarprov.go.id/baca-artikel-1093-pentingnya-gerakan-membaca-di-sekolahdasar.html

Musfiroh, T., \& Listyorini, B. (2016). Konstruk kompetensi literasi untuk siswa sekolah dasar. Litera, 15(1). https://doi.org/10.21831/Itr.v15i1.9751

Rohim, D. C., \& Rahmawati, S. (2020). Peran literasi dalam meningkatkan minat baca siswa di sekolah dasar. Jurnal Review Pendidikan Dasar: Jurnal Kajian Pendidikan dan Hasil Penelitian, 6(3), 230237.

Setiawan, A. A., \& Sudigdo, A. (2019). Penguatan literasi siswa sekolah dasar melalui kunjungan perpustakaan. Prosiding Seminar Nasional PGSD, 24-30.

Teguh, M. (2020). Gerakan literasi sekolah dasar. Jurnal Pendidikan Dasar Flobamorata, 1(2), 1-9.

Wulanjani, A. N., \& Anggraeni, C. W. (2019). Meningkatkan minat membaca melalui gerakan literasi membaca bagi siswa sekolah dasar. Proceeding of Biology Education, 3(1), 26-31.

https://doi.org/10.21009/pbe.3-1.4 